\title{
INTELLECTUAL HUMILITY AS STRENGHT IN THE PROCESSES OF THE FORMATION AND DEVELOPMENT OF KNOWLEDGE
}

\author{
Gintarė Gudeliauskè \\ Vytautas Magnus University, Lithuania
}

\begin{abstract}
The aim of the research: To describe the intellectual humility of a teacher as strength in the processes of forming and developing knowledge. Intellectual virtues presuppose the objective of deep, factual perception with a possibility to make mistakes. A lot of pedagogues lack the activities important for virtues without dependence on mood or similar supporting means (the total level of virtue). A teacher who distinguishes with intellectual humility, who belongs to the virtues of the first range (the initiation of learning process and its guiding towards the right direction) and has connection with other intellectual virtues, aims for coordinated learning relationship where the sense of equality is present, as well as broaden perspective, distinguishes with flexibility while re-considering convictions, fear which is felt by an intellectually humble person when he/she misses information or something is not understood. An intellectually humble teacher, developing his/her knowledge, distinguishes with the constant pursuit for development, ability to self-evaluate strengths and weaknesses, seeing relationship with others as perspective for development The definition of intellectual humility is usually related with the recognition that your convictions and opinions can be wrong. This virtue is concerned with the strengths of a teacher. Being an intellectually humble person opens possibilities to the independence of a learner while forming or developing knowledge and understanding. In this process the potential of colleagues is recognized, strong and weak points are firmly pointed out, intellectual arrogance is avoided. This presupposes more possibilities for the change of learning both to a learner and the one dependant on him/her.
\end{abstract}

Keywords: Intellectual humility, intellectual virtue, forming knowledge, developing knowledge.

\section{Introduction}

Pedagogical reality is versatile, requiring both integrity and multi-dimension at the same time. In such process of learning so that a positive change in a learner could occur, a teacher plays an important role. In the issue of the status of education the aspects are highlighted that "the generalized data of the observation of lessons show that in lessons teaching, organizing of the passive work of students predominate...”; " from the data of the assessed schools it can be claimed that overall attitude is missing in educational process"; "in almost every second school of the country (48,5 per cent of the assessed schools) it has been 
recommended to improve teaching attitude and educational methods” create problematics that something is wrong with the acting of a teacher, as it should be contextually (Lietuva. Švietimas šalyje ir regionuose, 2016). It is also confirmed by the statement in the report of NMVA (Nacionaline mokyklu vertinimo agentūra, 2015) that in school a teacher still actively participates and the selfevaluation of a pupil, as well as help when problems occur are not frequent phenomenon. In OECD PIAAC research (2016) the abilities of the reading and mathematical literacy of the Lithuanian adults are attributed to the $2^{\text {nd }}$ level, more than a half is of lower abilities, whereas in problem-solving while using technologies we are at the bottom of the list. So that a teacher could teach a pupil, he/she must learn himself/herself first, be oriented towards future, distinguish himself/herself with empathy, the ability to support a pupil in complicated situation, etc. In order to learn this, he/she has to be able to be humble. Virtues add to the formation of knowledge, whereas knowledge is the very core of everything, but the conception of intellectual virtues is impoverished (Taylor, 2016). The presence of intellectual virtues is a rare phenomenon. People lack the presence of the level of existence of complete virtues (Baeher, 2014). The attention of labour market is directed towards soft skills, comprising several intellectual virtues, such as curiosity, openness, intellectual autonomy and intellectual humility (Friedman, 2014). Education system has to educate certain intellectual and spiritual humility among learners (Cowley, 2017). Intellectual humility and respect are necessary in all the disciplines of education (Gruppen, 2014).

The aim of the research: To describe the intellectual humility of a teacher as strength in the processes of the formation and development of knowledge.

The questions of the research. The following questions are aimed to be answered: what is the significance of intellectual virtues in the process of the formation of knowledge? What is intellectual humility in the process of the development of knowledge?

\section{Methodology}

The methods of search. Systematic review is used as a search method, orienting towards the processes of the change of learning, when it is focused on intellectual humility.

The search of the database. The selection of scientific articles is performed in the database "Academic Search Complete". "Intellectual humility" is used as a key phrase in search. Having checked the articles found according to the search criteria, 8 articles were chosen. The search was restricted to the data of the research phenomenon in the perspective of education. Empirical articles were not found for analysis and in Lithuania it was researched performing psychological 
analysis (Marazaitė \& Kociūnas, 1998), it is mentioned in religious works (Rimkute, 2006; Vasiliauskaite, et al., 2012) thus theoretical articles are used for analysis.

The criteria of inclusion and elimination. While performing the selection of articles, the following criteria were used: the entire article published in scientific journals, the type of source - academic journal, the language of article - English, the main sources - educational sources and 2014-2019 were chosen.

Receiving and managing links. Only English texts in reviewed journals were chosen for further review. Information provided in forums and articles is used.

\section{Results}

\section{Intellectual virtues in the process of the formation of knowledge}

Intellectual virtue was considered to be essential in the process of education already in the times of Plato (Taylor, 2016).Nowadays teachers are assigned to give a lecture not only on academic contents, but also encourage the development of the virtues of the participants of lifelong learning. Intellectual virtues are character traits which are acquired during certain period of time (revising practice), they are available and non-requiring technical skills. There is a possibility to educate that in pupils (Taylor, 2016). They define intellectual features related with people, who, having received a new task or challenge, are able to quickly adapt to the needs of a new project (Ortwein, 2015). It is aimed to deeper perceive important issues by intellectual virtues. An intellectually virtuous person is the one who pays a lot of attention to details, tries to avoid mistakes and contemplates while performing researches, etc. They do not allow knowledge to exist, which occurs only because of epistemic success. Knowledge is based on reasoned convictions, thus it is factual, whereas understanding is connected with the perception of the structure of a certain piece of reality (Taylor, 2016). Virtuous agents not only aim for certain convictions, but also want to perceive structural relationship between these convictions. Reaching for knowledge, it is necessary to search for certain convictions in order to eradicate wrong ones, paying most of attention to the truth and its correction. That is connected with proceeding to understanding roader issues which contain these convictions.

Some firm opinions are not compatible with openness. To recognize that there is a possibility to make a mistake and somebody else is making a mistake is the recognition of non-perfection. It is connected with the attitude as possibly wrong, but that attitude is not weakened (Taylor, 2016). A teacher is a person who creates various learning situations including pupil generation after generation. Aiming for improvement, open attitude should be a component of activity for a teacher. 
Gudeliauske, 2020. Intellectual Humility as Strenght in the Processes of the Formation and Development of Knowledge

The theory of knowledge, based on virtues, aims to bind knowledge with moral concepts (Salloum, 2017).

1. The epistemology of virtues is normative while asking oneself questions which include not only what we have to know (remember, reason, inquire), but also questions how we should know and what is good cognition.

2. The epistemology of virtues transfers the location of assessment from individual convictions and hints to virtues and cognitive manner.

The levels of intellectual virtues are distinguished according to criteria when a certain person is $-\mathrm{S}$, virtue $-\mathrm{V}$ (Baehr, 2014):

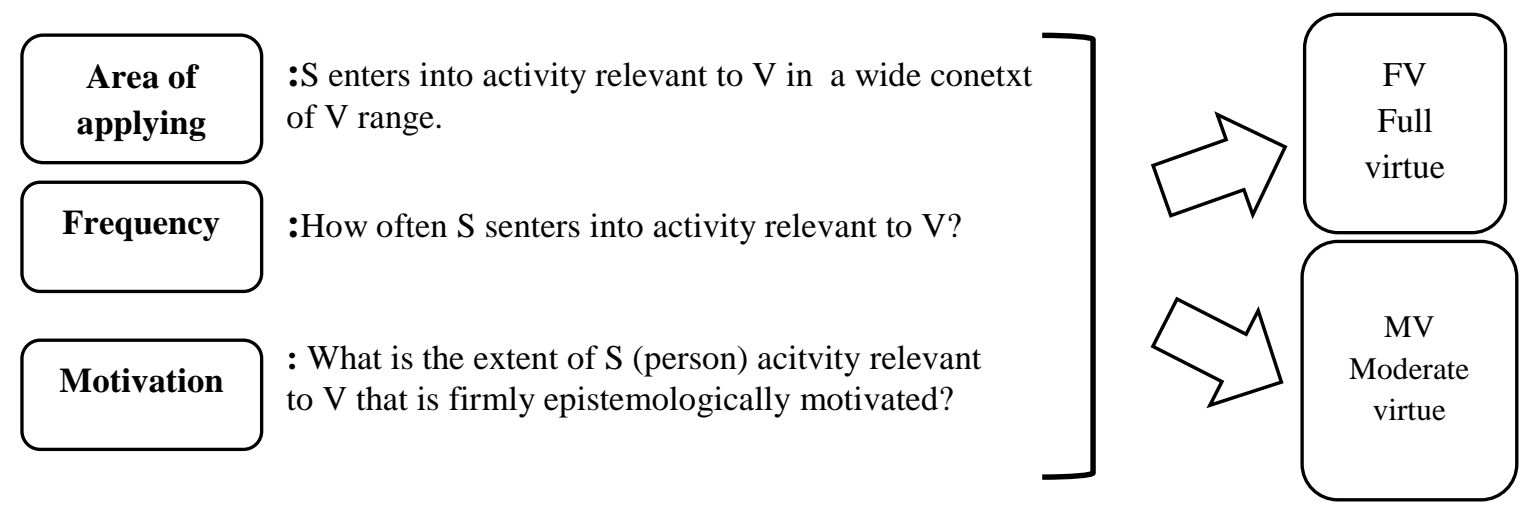

Figure 1 The levels of intellectual virtues according to 3 criteria

Full virtue: (a) $\mathrm{S}$ enters into activity relevant to $\mathrm{V}$ in all (or almost all) contexts relevant to V; (b) in all (or almost all) contexts S always (or almost always) enters into activity relevant to $\mathrm{V}$ when it is needed; (c) in all (or almost all) contexts relevant to $\mathrm{V}$ the active performance of $\mathrm{S}$ (person) is always (or almost always) firmly epistemologically motivated.

Moderate virtue: (a) $\mathrm{S}$ enters into activity relevant to $\mathrm{V}$ in several contexts relevant to V; (b) in several (separate) contexts S regularly enters into activity relevant to $\mathrm{V}$ when it is needed; (c) in several contexts relevant to $\mathrm{V}$ the active participation of $\mathrm{S}$ (person) is regularly epistemologically motivated.

Educating virtues is closely related with the educating of compassionate virtues. The teacher is an example of it to a student. The best case is when a teacher distinguishes with the possessing of total virtue.

\section{Intellectual virtue - humility}

One of the statements is that education should not only provide confidence while evaluating simply accessible sources of meaning, but it should also teach intellectual humility (Cowley, 2017). Intellectual humility is the core of self- 
evaluation. It is described as dispositional profile including cognitive, behavioural, motivational and emotional responses to perceive one's limitations (Priest, 2017). Ortwein (2015) distinguishes 9 intellectual virtues, one of them is intellectual humility. They are divided into three categories:

1. To start learning process and guide it towards proper direction.

2. To ensure that learning process would be fluent.

3. To overcome the challenges of productive leaning.

The virtues of range 1 . These character traits involve curiosity, wish to wonder and raise questions why it is happening. It is related with the wish to explore. These virtues have the attitude of intellectual humility in the perception within the limits of its intellect. Also, there is anxiety because of advantages and status. Preparation is evidenced by autonomy, active, the ability of thinking directed towards oneself, ability to reason oneself. And it involves knowing when it is possible to trust others in learning context. The following virtues belong to this range: curiosity, intellectual autonomy and intellectual humility.

Curiosity. It enables to look for answers even when it is not planned in advance. It is aiming to fill in gaps. Intellectual autonomy.

Intellectual humility. People who do not have impulses due to their charming or enviable features evidence intellectual humility (IH). The ones who only slightly stress that they have such features of which they can be proud of. These are people to whom these features and winnings are not very important. Suitable pride is psychologically healthy. Intellectual arrogance is opposite to that. A person who distinguishes with intellectual arrogance, in our case a teacher, demonstrates attitude superior to others. In this way the expanding of his/her attitude is possibly limited and there is even the rejection of other, more persuasive attitudes. IH is a necessary intellectually honest evaluation (accounting) of one's abilities.

Without possessing/developing the above-mentioned intellectual virtues, problematicity occurs while speaking about the virtues of the $2^{\text {nd }}$ range. This range is "filled in" by attentiveness, which keeps attention, focus on important details, the nuances of meaning; carefulness - intellectual accuracy: understanding of good thinking and the requirements of learning, as well as sensitivity to others. It provides deeper meanings, possibility to quickly pay attention and avoid traps and mistakes. Also, easy answers are not enough. Honesty with regard to own understanding. That is the ability to perform certain actions not under the circumstances of fear, but under the conditions of intrinsic motivation.

$3^{\text {rd }}$ range. Coping with challenges distinguishes with open attitude. Openness is the feature of educated mind. It is necessary as pedagogical component. Openness is one of "doubly valuable" virtues, the aim of which is: both recognition and understanding (Taylor, 2015). Ortwein (2015) claims that 
such a person demonstrates epistemic humility. There are teachers the ideas of whom are unsuitable and inflexible even if contrary evidence is given. Such behaviour weakens their possibilities to reach understanding, knowledge and wisdom, as they just refuse to change their ideas and convictions. The teachers of open attitude are ready to listen to the contrary evidence and if there is a need, specify their convictions. IHsupports openness, but these two virtues are different (Taylor, 2015). The author, describing an open person, also names IH as one of the aspects:

1) Widely motivated to reach for knowledge and understanding;

2) Especially motivated to consider the evidence and arguments possessed when new convictions or understandings are being formed and retained steady;

3) One has to be intellectually humble;

4) Intellectually courageous and thorough. Closed people even do not want to consider how new evidence or arguments could expand their understanding.

Courageous activities are also attributed to this range. Courageous activities can be motivated by some other virtues: justice, sympathy, generosity, love of knowledge.

\section{Intellectual humility in the process of the development of knowledge}

Indoctrination causes closed thinking, whereas closed thinking threatens the striving for knowledge and understanding (Taylor, 2016). The development of knowledge is encouraged by such virtues as intellectual sobriety, persistence, honesty and humility (Salloum, 2017). Thoughts can be refused too earlydue to the lack of humility and persistency. $\mathrm{IH}$ is important in the process of the development of knowledge of a teacher and distinguishes with several essential characteristics (see Table 1).

Table 1 The Characteristics of Intellectual Humility in the Process of the Development of Knowledge

\begin{tabular}{|l|l|}
\hline The part of the process of the development of knowledge & Characteristics \\
\hline $\begin{array}{l}\text { IH is perceived as motivation and ability to exactly evaluate } \\
\text { one's intellectual falseness which can include the lack of } \\
\text { knowledge and understanding (Taylor, 2016). }\end{array}$ & $\begin{array}{l}\text { Ability to evaluate, recognize } \\
\text { one's weak, limiting and } \\
\text { strong points. }\end{array}$ \\
\hline $\begin{array}{l}\text { Aiming to be IH, we have to recognize the limits of our } \\
\text { knowledge and understanding. For that we need to } \\
\text { acknowledge that understanding can be deepened, expanded } \\
\text { or more connected with the truth (Taylor, 2016). }\end{array}$ & \\
\hline
\end{tabular}




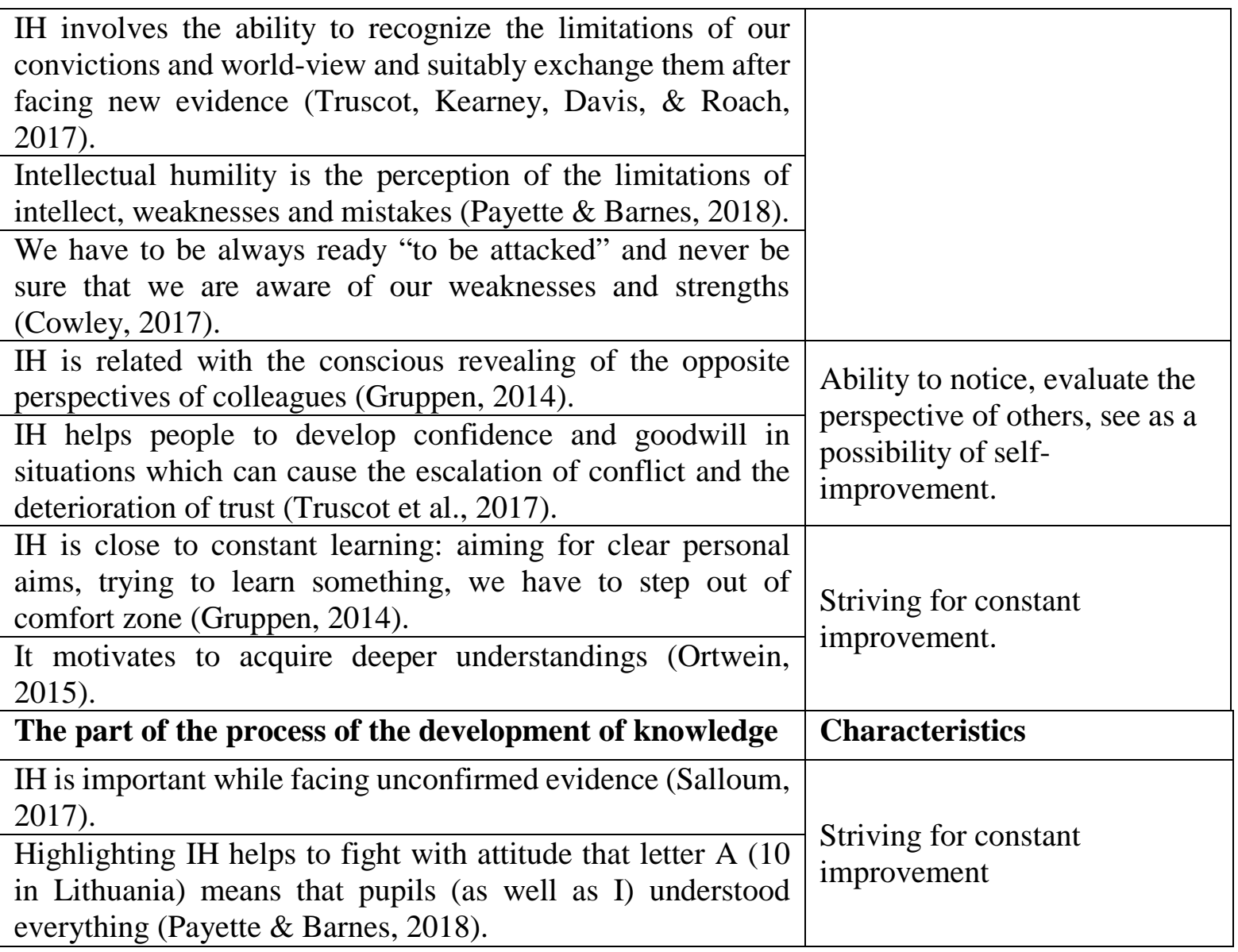

IH can be understood as average between the contradictory discrepancies of intellectual arrogance (non-evaluation of intellectual falseness) and intellectual modesty or duty (overestimating of intellectual treachery) (Taylor, 2016). According to the data of the table we can see that in the process of developing knowledge the most distinctive characteristics of an IH person, in our case teacher, are reaching for constant improvement, the ability to self-evaluate strengths and weaknesses, relationship with others as the perspective for improvement.

Limitations. This systemic review has limitations. The first limitation is related with the fact that without discovering empirical articles, theoretical ones are used for analysis. The second - due to the main keywords. Only the phrase intellectual humility is used in search without using possible equivalents. The third - sources used for analysis are only in English.

\section{Discussion}

In literature it has been noticed that teachers usually overestimate their knowledge and are too much confident in their assessment. The fact that we often make mistakes while evaluating what we know and do not know requires to 
demand IH and behaviour accompanying it with colleagues even when we believe that we know. Recognizing what we ignore can be as much important as what we pay attention to (Gruppen, 2014). The profession of a teacher is as if dictating, favourable to appear for such stereotypes as "a teacher cannot be the one who does not know", "a teacher cannot make mistakes", etc. It influences that a teacher often ignores a lot of things, suppresses, does not recognize, as it is safer "to live" like that. Another side also exists, which is related with examples when knowledge is overestimated due to the role in a lesson, community, etc. In a lesson a teacher takes the role of a more advanced one in learning and it can form contrariety to IH. If we expressed the above-mentioned statement by a phrase, it would sound like that: "how can I, with so much experience, knowledge, abilities, yield to somebody". The existence of a similar kind of such statements of meaning occurs because IH is understood as weakness, there is a lack of deeper perception about the significance of IH in the processes of the formation and development of knowledge. IH threatens that one will have to change whereas it is rarely a comfortable or easy activity. Our natural response to contradictions is to resist, not to accept and not consider regarding the possible validity of knowledge, convictions and priorities (Gruppen, 2014). Here a tight relationship with openness appears. Taylor (2016) describes an open person who has a tendency towards the improvement of knowledge and understanding, one of the components is IH. An open teacher:

1) Widely motivated to aim for knowledge and understanding;

2) Especially motivated to consider the evidence and arguments possessed when he/she forms new convictions or understandings and retains them steady;

3) Has to be intellectually humble;

4) Intellectually courageous and thorough.

Closed teachers even do not want to consider how new evidence or arguments could expand their understanding. An IH teacher is aware that there is always space for improvement and that IH allows to recognize his/her weak points (Payette \& Barnes, 2018).

"Without the roles of teachers traditionally distinguished in educational science - the teacher of a subject (the conveyor of information, leader of teaching process, organizer of educational process) and an educator (a cooperating senior friend, the leader of a class), such roles as a consultant, the leader of teaching processes, encourager, researcher, catalyst, mediator of changes, social pedagogue, cooperating colleague, etc.) appear.” (Dudaitė \& Prakapas, 2016). Stephen et al. (2017) indicate IH as important in the relationship of consultations:

Open attitude towards a consulted person includes ability to balance ultimate perspectives. They do not reject ideas contradicting to their ideas, but they also do not accept without essential evidence. A consultant can only change 
convictions only being completely sure. Consultants with lower IH can choose stricter consultation methods. They can take over the control of the process of problem solving and offer fixed suggestions based on their competence, but without considering the pedagogical convictions or context of the consulted. $\mathrm{IH}$ should neither prioritize nor encourage their attitude. There should be cooperating attitude. An important aspect of IH - respect to others' convictions encourages to honestly exchange ideas. One can express opinion while asking for the opinion of the consulted.

A teacher has often assumed the role of an expert and consultation relationships which are oriented towards IH lose possibilities for realization. In this way there is no impulse forward in none of the person participating in this relationship. There is a frequent situation when one does not want, does not see, etc. reasons are because of communication with a colleague who can be the stimulant of change. Colleagues help us respond to our attitude and provide alternative perspectives (Gruppen, 2014). Alternative perspectives open wider, more favourable conditions to a teacher for going deeper.

Intellectual virtues (and vices) form the way people make contacts - the manner of their contact with outer world. They serve as a certain moral system or infrastructure directing people towards positive or negative intellectual activity (Ortwein, 2015). Freire (2000) states that dialogue is impossible without humility because naming the world people constantly re-create it and there is no space for pride. The philosopher highlights that if at least one aiming for a common goal to learn and act lacks humility, dialogue is not further developed. Freire (2000) raises such questions as: "How can I establish a dialogue, if I always consider others to be inept, but never perceive my knowledge?; How can I continue dialogue, if I think I am separated from others, the "I" of whom cannot acknowledge the "I" of others?; How can I participate in a dialogue, if I feel I am the member of the group of "real" people, to whom truth and knowledge belong and who overtake all the rest who do not belong to this group, consider them to be "those people" or the populace?; How can I participate in a dialogue, if I follow the assumption that the naming of the world is the task of the elite and that the participation of the folk in history is to be avoided, as it marks degeneration?; How can I participate in a dialogue, if I do not recognize the input of others which even hurts me?; How can I participate in a dialogue, if I am afraid that I will be expelled and the possibility to be expelled only makes me suffer, feel weak?". Continuing the thoughts of the philosopher, we stress that "raising" yourself above others, as well as dialogue, creating new meanings, are incompatible. Teachers who lack IH or have lost it cannot be somebody's partners naming the world. The wish and aim to find out more than they know now are stressed. 
Gudeliauske, 2020. Intellectual Humility as Strenght in the Processes of the Formation and Development of Knowledge

\section{Conclusions}

Personal transformation is the main basis of the growth of the character of intellect. A teacher has special responsibility to be open to pedagogics, constantly try to improve the understanding of his/her area. Most of them have become intellectually arrogant and stick to the information received before. There are conflicts which do not allow teachers to be intellectually humble, they include other professional virtues like critical scepticism, competition and trust. The development of knowledge is encouraged by IH. The conception of IH as strength would enrich awareness about the possibilities of the development of the knowledge and understanding of a teacher. Its absence in learning is understood as considering others (pupils, heads, colleagues) to be ignorant, non-recognizing of their "I", non-participation in dialogue, as the input of others is not recognized, which hurts, etc. A teacher, being intellectually humble, can "ease" or "quicken" moving towards the bigger autonomy of a learner. And that is related with the ability to create learning conditions for a pupil and reach for positive learning impact. We can never reveal all the mysteries of reality, but in some situations we can recognize ourselves. Self-cognition without intellectually humbly recognizing one's ignorance can cause many hindrances, limitations to a teacher.

\section{References}

Baehr, J. (2016). Is intellectual character growth a realistic educational aim? Journal of Moral Education, 45(2), 117-131.

Bendrojo ugdymo mokyklų veiklos kokybė. Nacionalinès mokyklų vertinimo agentūros metinis pranešimas. (2015). (5).

Cowley, C. (2017). Education, Despair and Morality. Journal of Philosophy of Education, 51(1), 298-309.

Dudaite, J., \& Prakapas, R. (2016). Lietuvos mokytojų, dirbančių su „Activinspire” interaktyviaja sistema, patirtys organizuojant pamokos darbą. Socialinis darbas, 14(2), 199-209.

Freire, P. (2000). Kritinès sąmonės ugdymas. Vilnius: Tyto Alba.

Friedman, T. (2014). How to get a job at Google. New York Times, February 22. http://www.nytimes.com/2014/02/23/opinion/sunday/friedman-how-to-get-a-job-atgoogle.html

Gruppen, L.D. (2014). Humility and respect: core values in medical education. Medical Education, 48, 53-58.

Lietuva. Švietimas šalyje ir regionuose. Mokinių pasiekimai (2016). Vilnius: Švietimo aprūpinimo centras.

Marazaitè, I., \& Kociūnas, R. (1998). Psichologinè nuolankumo analizè. Psichologija, 18, 65-81.

Ortwein, M.J. (2015). The Regulation of Understanding throgh Intellectual Virtue. Jornal of Thought, 71-85. 
Pagrindiniai suaugusiųu gebejjimai. PIAAC tyrimo rezultatai. Retrieved from https://www.oecd.org/skills/piaac/

Payette, P., \& Barnes, B. (2018). Coaching for Intellectual Humility and Intellectual Perseverance. The National Teaching \& Learning Forum, 27(3), 4-6.

Priest, M. (2017). Intellectual Humility: an interpersonal theory. Ergo, 4(16), 463-480.

Rimkutè, A. (2006). Religijos terminijos tvarkyba Draugijoje. Terminologija.

Salloum, S. (2017). The pace of practical wisdom in science education: what can be learned from Aristotelian ethics and a virtue-based theory of knowledge. Cultural Studies of Science Education, 12, 355-367.

Taylor, R.M. (2016). Open-mindedness: an Intellectual Virtue in Pursuit of Knowledge and Understanding. Educational theory, 66(5), 599-618.

Truscot, S.D., Kearney, M.A., Davis, D.E., \& Roach, A.T. (2017). Intellectual Humility and Morality as Consultee-Centeed Consultation Epistemologies. Journal of Educational and psychological consultation, 27(1), 26-142.

Vasiliauskaitè, A. (2016). Sielovados principai Šv. Benedikto regulos tekste. Soter: religijos mokslo žurnalas. 